\title{
Pengaruh Edukasi Virtual Menyikat Lidah Terhadap Kondisi COATED TONGUE Pada Siswa SMP Negeri 1 Pematang Tanah Jawa di Masa Pandemik Tahun 2020
}

\author{
Junita Elvrida Doloksaribu ${ }^{1}$ Suci Erawaty ${ }^{2}$ Molek $^{3}$ \\ Faculty of Dentistry, University Prima Indonesia \\ Email: junitaelvridadoloksaribu@gmail.com esuci64@gmail.com
}

\begin{abstract}
The tongue is one of the vital organs found in the oral cavity. The tongue has a natural membrane when it is healthy. But if cell failure occurs, it causes infection on the white surface layer of the tongue called coated tongue. Tongue cleaning is recommended to prevent these infections. Therefore, people need to get education about tongue cleaning with virtual education. Dental and oral health practices still need to be improved. One of them is by providing virtual education. Virtual education refers to the learning process through the internet network whose application is intended to overcome the problem of separation of space and time between students and teachers via smartphones. The purpose of this study was to determine the effect of virtual tongue brushing education on coated tongue conditions in students of SMP Negeri I Pematang Tanah Jawa during the pandemic in 2020. This type of research is a quasi experiment with pretest and posttest designs. The number of samples is 20 people. The determination of the sample in this study used inclusion and exclusion criteria. The analytical test used was Wilcoxon. In the study, it was found that the difference in the conditions of coated tongue before and after virtual education was $p$ value $=0.000<0.05$ ). The conclusion of this study is that there is an effect of virtual education on the condition of coated tongue in SMP Negeri I Pematang Tanah Jawa with p value $=0.000$.
\end{abstract}

Keywords: Virtual education, tongue, coated tongue

\begin{abstract}
ABSTRAK
Lidah merupakan salah satu organ vital yang terdapat dalam rongga mulut. Lidah mempunyai selaput alami ketika sehat. Tetapi jika kegagalan sel terjadi, maka menimbulkan infeksi pada lapisan permukaan lidah berwarna putih disebut coated tongue. Pembersihan lidah disarankan untuk mencegah terjadinya infeksi tersebut. Oleh karena itu, masyarakat perlu mendapatkan edukasi mengenai pembersihan lidah dengan edukasi virtual. Praktek kesehatan gigi dan mulut tetap harus ditingkatkan. Salah satunya dengan memberukan edukasi virtual. Edukasi virtual mengacu pada proses pembelajaran melalui jaringan internet yang penerapannya ditujukan untuk mengatasi masalah keterpisahan ruang dan waktu antara siswa dan pengajar melalui smartphone. Tujuan penelitian ini adalah untuk mengetahui pengaruh edukasi virtual menyikat lidah terhadap kondisi coated tongue pada siswa SMP Negeri I Pematang Tanah Jawa di masa pandemi tahun 2020. Jenis penelitian adalah eksperimen semu (quasi experiment) dengan desain pretest dan posttest. Jumlah sampel 20 orang. Penentuan sampel dalam penelitian ini menggunakan kriteria inklusi dan eksklusi. Uji analisis yang digunakan adalah wilcoxon. Pada penelitian diperoleh perbedaan kondisi coated tongue sebelum dan sesudah edukasi virtual adalah $\mathrm{p}$ value $=0,000<0,05$ ) Kesimpulan penelitian ini yaitu ada pengaruh edukasi virtual terhadap kondisi coated tongue pada SMP Negeri I Pematang Tanah Jawa dengan $\mathrm{p}$ value $=0,000$.
\end{abstract}

Kata Kunci: Edukasi virtual, lidah, coated tongue

\section{PENDAHULUAN}

Oral health is integrated with body health that we need to take care seriously. Tongue is one of vital organ in oral cavity that has different functions, for instance articulation, taste perception, and mastication (Radhika et al., 2016).

Tongue has white natural membrane caused by epithelium exfoliations (Lewis and Jordan, 2016).
Tongue is consisted with a lot of papillae, where colonies of fungus and bacteria lived within dorsal tongue. Those colonies could cause some problems in oral cavity (Hamid et al., 2015).

Infection can occur at teeth or soft tissue because of inadequate oral cavity hygiene (Nuraeny et al., 2017). The research was held by Riskedas in 2018 showed that Indonesia population that could brush their teeth correctly only $2,3 \%$ with national caries incidence (DMF-T) only 4,6. There wasn't 


\section{Jurnal Ilmiah Pannmed (Pharmacyst, Analyst, Nurse, Nutrition, Midwivery, Environment, Dental Hygiene) Vol. 16 No. 1 Januari - April 2021}

any data regarding coated tongue incidence (Indonesia Health Ministry, 2019).

Coated tongue is clinical condition that characterized by pseudo membrane because of accumulated debris, unsuccessful desquamated keratin cells and microorganism. Coated tongue patients come to the dentist or public health center mostly with bad oral odor. Research showed that oral lesion is one of coated tongue case that could be found in any age group.

One of the basic steps to prevent oral disease and maintain oral hygiene is brushing teeth and tongue. To prevent infection and pathology condition, tongue cleaning could decrease debris and microorganism accumulation in oral cavity.

In several countries, suggestions regarding tongue cleaning had been conducted, like scraping and brushing. (Rickenbacher et al., 2019). American

Dental Association recommended tongue cleaning for oral hygiene (Mark, 2015). Nevertheless, there weren't any people understand how to brush teeth properly. (Rahardjo et al., 2015)

Early 2020, a new type of pneumonia disease from Wuhan, Hubei Province had been spreading around the world massively around 190 countries and territory. This pandemic called COVID-19 (Coronavirus disease 2019) that caused by Severe Acute Respiratory Syndrome Coronavirus-2 (SARS COVID-2). This outbreak has massive impacts for economic and social problems. (Susilo et al., 2019)

Indonesia Health Ministry took several actions regarding prevention and controlling COVID-19 infection. Those were included using and practicing hand sanitation, avoiding hand contact around eyes, nose and mouth, covering mouth and nose while coughing or sneezing, using medical mask and social distancing (approximately one meter) with other people.

There were a lot of people who infected and died with Covid-19. Therefore, Indonesia Dentistry Association (PDGI) issued notification letter number 2766/PBPDGO/III-3/2000 about Public Dentistry Guideline during Covid-19 Pandemic, which one of them discussed about dental practice prohibition. Meanwhile, oral hygiene is one of important matter for dental health. Because of this urge situation, oral hygiene education must be done virtually. Virtual education is one of learning method using internet connection. Virtual education aim to practice social distancing condition between student and teacher using smartphone or any electronic devices (Said 2014).

This research were held in Junior High School 1 at Pematang Tanah Jawa, Siantar during Covid-19 pandemic. According to preliminary survey, there are 100 students with coated tongue and 30 of them were from ninth grade. All of the students were from different social region and backgrounds, which all of them had different cuisine and culture. From those previous reason, "The Effect of Tongue Brushing Virtual Education with Coated Tongue Incident of Junior High School 1 Students at Pematang Tanah Jawa During Covid-19 Pandemic in 2020" was conducted by researchers.

\section{METHODS}

This research used quasi experiment with pretest and posttest design. Population for this research were students in Junior High School 1 Pematang Tanah Jawa who had smartphone, which 20 of them had fulfilled inclusion and exclusion criteria. All the data were collected with coated tongue score and were analyzed with Wilcoxon test.

\section{RESULT}

3.1 Distribution Frequency of Participant's Characteristic Participant's characteristic based on Table 1 showed that participants were at the age of 14 years old $(\mathrm{n}=8(40 \%)), 13$ years old $(\mathrm{n}=7$ $(35 \%))$, and 15 years old $(n=5(25 \%))$. Based from the gender, 12 participants were male $(60 \%)$ and 8 participants were female (40\%).

Characteristics Frequency Percentage Age

\begin{tabular}{|rcc|}
\hline $\mathbf{1 3}$ & 7 & 35.0 \\
$\mathbf{1 4}$ & 8 & 40.0 \\
\hline $\mathbf{1 5}$ & 5 & 25.0 \\
\hline Gender & & \\
Male & 12 & 60.0 \\
Female & 8 & 40.0 \\
\hline
\end{tabular}

\subsection{Coated Tongue Condition Mean Score Before and After Virtual Education}

Based from Table 2, it showed that coated tongue mean score before virtual education was $1,95 \pm 0,394$ and after treatment $1,15 \pm 0,366$.

\begin{tabular}{|c|c|c|}
\hline Sample & Before & After \\
\hline 1 & 2 & 1 \\
\hline 2 & 2 & 1 \\
\hline 3 & 1 & 1 \\
\hline 4 & 2 & 1 \\
\hline 5 & 2 & 1 \\
\hline 6 & 2 & 1 \\
\hline 7 & 1 & 1 \\
\hline 8 & 2 & 1 \\
\hline 9 & 2 & 1 \\
\hline 10 & & \\
\hline 11 & 2 & 1 \\
\hline
\end{tabular}




\begin{tabular}{|c|c|c|}
\hline 12 & 2 & 1 \\
\hline 13 & 2 & 1 \\
\hline 14 & 3 & 2 \\
\hline 15 & 2 & 2 \\
\hline 16 & 2 & 1 \\
\hline 17 & 2 & 1 \\
\hline 18 & 2 & 1 \\
\hline 19 & 2 & 1 \\
\hline 20 & 2 & 1 \\
\hline Mean & 1.95 & 1.15 \\
\hline SD & 0.394 & 0.366 \\
\hline
\end{tabular}

\subsection{Coated Tongue Condition Before and After Virtual Education}

According to Table 3.3, it showed that mean score of coated tongue before virtual education was $1,95 \pm 0,394$ and after treatment $1,15 \pm 0,366$. Based from

Wilcoxon test, the result of $p$ value $=0,000$ $(p<0.05)$, that means there were significant difference in coated tongue before and after virtual education. It concluded that there were any significant effects of tongue brushing virtual education with coated tongue incident of Junior High School 1 students at Pematang Tanah Jawa.

\begin{tabular}{|c|c|c|c|}
\hline \multicolumn{4}{|c|}{ Treatme Mean $p$ Descriptio nt Score valu n } \\
\hline Before & $\begin{array}{c}1,95 \pm 0,39 \\
4\end{array}$ & $\begin{array}{c}0.00 \\
0\end{array}$ & $\begin{array}{c}\text { There } \\
\text { were any }\end{array}$ \\
\hline After & $\begin{array}{c}1,15 \pm 0,36 \\
6\end{array}$ & & $\begin{array}{l}\text { significant } \\
\text { difference }\end{array}$ \\
\hline
\end{tabular}

\section{DISCUSSION}

\subsection{Participant Characteristic}

From this research, participants were students in Junior High School 1 Pematang Tanah Jawa. This research showed that the majority of student's age were 14 years old. This research was different with Nur'aeny and Sari (2016) research that showed 75\% participants who suffered from coated tongue were 70-80 years old elders. Another research conducted by Setiadhi and Wihardja (2019) showed that some of the participants were 7 years old $(18,9 \%)$.

Age is one factor that affecting people's health. Research conducted by Setiadhi and Wihardja (2019) showed there are any significant correlation between age and soft tissue condition. As people are getting old, the risk to get chronic diseases are much higher, which one of them is coated tongue. Participant's average ages were 14 years old.

Lesar et. al (2015) claimed that oral hygiene prevalence are getting lower when children turn into adolescent. School age students doesn't have any good motivation to maintain their body health and still dependent from their parents (Setiadhi and Wihardja 2019). Result of this research showed coated tongue incident was affected by their knowledge and habits to maintain their oral health. According to the participant's gender, the majority of participants are male students. This results matched with another research that was conducted by Idham et al., (2013) that $60 \%$ orphans that used tongue scraper were male. This result matched with another research that was conducted by Hamid et al., that $60 \%$ tongue scraper user were male students. From this research, it concluded that female students had lower tongue hygiene compared with male students.

Coated tongue is a clinical condition where pseudo membrane occurs on the tongue surface because of debris and food accumulation, unsuccessful desquamated keratin cells, and microorganism like fungus or bacteria. Coated tongue usually found in person who consumes soft or liquid food and this condition occurs in every stage of age and gender (Nur'aeny et al., 2017; Ragunathan et al., 2019).

Researchers assumed that coated tongue condition was affected by tongue hygiene, age and gender. If we taking care of our tongue seriously, the risk of getting coated tongue could be lower without proper care.

\subsection{Virtual Education Effects on Coated Tongue Condition}

From this research, it concluded that average score of coated tongue before virtual education was $1,95 \pm 0,394$ and after virtual education $1,15 \pm 0,366$. Based on Wilcoxon test, the result of $\mathrm{p}$ value $=$ $0,000(p<0,05)$ means there were any significant difference in coated tongue condition before and after virtual education. It could be conclude that there were any significant effect of virtual education with coated tongue condition in Junior High School 1 Pematang Tanah Jawa, Result of this research matched with Nuraeny et al., (2017) stated that education implementation and evaluation to healthcare candidate brought positive effect with development of coated tongue prevention.

Another cause of coated tongue is microorganisms. When microorganisms are releasing pigment, the surface of tongue turn into yellow or black (Funahara et al., 2018). There are many method to give education, for instance virtual education. Virtual education is a learning method that using internet. Virtual education implementation was aimed to overcome distance 


\section{Jurnal Ilmiah Pannmed (Pharmacyst, Analyst, Nurse, Nutrition, Midwivery, Environment, Dental Hygiene) Vol. 16 No. 1 Januar i - ApriI 2021}

between student and teacher with smartphone. Students can get learning materials designed with packages from the internet site from smartphone.

Researches assumed that virtual education could be alternative learning methods to learn coated tongue condition for students.

\section{CONCLUSION}

Mean score of coated tongue condition in Junior High School 1 Students in Pematang Tanah Jawa before virtual education was $1,95 \pm 0,394$.

Mean score of coated tongue condition in Junior High School 1 Students in Pematang Tanah Jawa after virtual education was $1,15 \pm 0,366$.

Based on Wilcoxon test, it stated that there were any significant effects of coated tongue condition in Junior High School 1

Pematang Tanah Jawa with $\mathrm{p}$ value $=0.000$ $(\mathrm{p}<0.005)$.

\section{REFERENSI}

1. Geest, S-D; I. Laleman; W. Teughels; C. Dekeyser; M. Quirynen. 2016. Periodontal disease as a source of halitosis: a review of the evidence and treatment approaches for dentists and dental hygienists. Periodontology 71:213227

2. Hamid, H; R. Aulia; dan R. Samad. 2015. Efektivitas penggunaan Tongue scraper terhadap penurunan indeks tongue coating dan jumlah koloni bakteri anaerob lidah. Jurnal Dentofasial 10(1):32- 35.

3. Idham, R. Nurrahma; dan R. Samad. 2013. Using tounge scraper and oral-dental hygiene after counseling at children of orphanage Ashabul Kahfi Makassar. Dentofasial 12(1):1923.

4. Julaeha, S. 2011. Virtual learning: pemanfaatan teknologi informasi dan komunikasi untuk meningkatkan kualitas pembelajaran. Majalah Ilmiah Pembelajaran 7(2):

5. Kemenkes. 2019. Riset Kesehatan Dasar Tahun 2018. Kementerian Kesehatan RI, Jakarta.

6. Lewis, M-A-O; and R-C-K.Jordan. 2016. Penyakit Mulut Diagnosis \& Terapi, Edisi 3. Jakarta: EGC.

7. Mark, A-M. 2015. Targeting bad breath. JADA, 146(12). 8. Nur'aeny, N; dan K.I. Sari. 2016. Profil lesi mulut pada kelompok lanjut usia di Panti Sosial Tresna Wreda Senjarawi Bandung. Majalah Kedokteran Gigi Indonesia 2(2):74-79.

9. Nur'aeny, N; W. Hidayat; D. Zakiawati; dan I-S. Wahyuni. 2017. Edukasi dan evaluasi terhadap kondisi coated tongue bagi kader kesehatan Puskesmas Ujung Berung Indah. Jurnal Pengabdian Kepada Masyarakat 1(1):2427.
10. Radhika, T; N. Jeddy; and S. Nithya. 2016. Tongue prints: a novel biometric and potential forensic tool. Journal of Forensic Dental Sciences 8(3):117-119.

11. Ragunathan, M; E. Herawati; dan L. Epsilawati. 2019. Gambaran klinis dan faktor predisposisi dari coated tongue pada mahasiswa gigi klinik Fakultas Kedokteran Gigi Universitas Padjadjaran. Jurnal Radiologi Dentomaksilofasial Indonesia 3(3) : 17-20.

12. Rahardjo, A; D-A. Maharani; B. Kiswanjaya; E. Idrus; J. Nicholson; P-J. Cunningham; F. Schafer. 2015. Measurement of tooth brushing frequency, time of day and duration of adults and children in Jakarta, Indonesia. Journal of Dentistry Indonesia, 21(3):85-88.

13. Rickenbacher, O; C. Filippi; A. Zucher; and A. Filippi. 2019. Acceptance of a a tongue vacuum cleaner among children and evaluation of tongue cleaning at home. Swiss Dental Journal, 129(2).

14. Said H. 2014. Pengembangan model pembelajaran virtual untuk meningkatkan efektivitas pembelajaran pada madrasah negeri di kota Pare-pare. Lentera Pendidikan 17(1): 18-33. 